\title{
STORAGE OF MOMBIN FRUITS COATED WITH CASSAVA STARCH AND PVC FILM $^{1}$
}

\author{
RAIMUNDA VALDENICE DA SILVA FREITAS ${ }^{2}$, PAHLEVI AUGUSTO DE SOUZA ${ }^{2}$, EVANDO LUIZ COELHO $^{3}$, \\ FRANCISCO XAVIER DE SOUZA ${ }^{4}$, HIRLLEN NARA BESSA RODRIGUES BESERRA ${ }^{5}$
}

\begin{abstract}
The mombin tree (Spondias mombin L.) is found in almost all regions of Brazil. Fresh and processed mombin fruits are increasingly demanded by the market. The objective of this work was to evaluate the post-harvest characteristics of mombin fruits coated with cassava starch and PVC film. Fruits from the mombin cultivar Lagoa-Redonda were harvested at physiological maturity in Limoeiro do Norte, State of Ceará, transported to the Chemistry Laboratory of the Ceará Federal Institute, Limoeiro do Norte campus, and stored for 8 days at $29.7^{\circ} \mathrm{C}$ and $59 \%$ of relative humidity. A completely randomized experimental design in a $3 \times 5$ factorial arrangement was used, with three coating types (control, cassava starch at 3\%, and cassava starch at 3\% combined with PVC film) and five storage times $(0,2,4,6$ and 8 days), four replicates and five fruits per plot. The fruit skin color, external appearance, soluble solids (SS), titratable acidity (TA), SS/TA ratio and weight loss were evaluated. The PVC film was effective in maintaining the fruit external appearance and decreasing weight loss. The use of cassava starch was not as efficient as the PVC film for conserving mombin fruits. The post-harvest life of fruits was 8 days for those treated with cassava starch or cassava starch combined with PVC film, and 6 days for the control.
\end{abstract}

Keywords: Spondias mombin L.. Coating. Conservation. Post-harvest life.

\section{ARMAZENAMENTO DE CAJÁS RECOBERTOS COM FÉCULA DE MANDIOCA E FILME PVC}

RESUMO - A cajazeira é encontrada em quase todas as Regiões do Brasil vem apresentando crescente demanda de frutos in natura e produtos processados. Este trabalho teve como objetivo avaliar o comportamento pós-colheita de frutos de cajá recobertos com fécula de mandioca e filme PVC. Para realização deste trabalho utilizaram-se frutos da cajazeira do genótipo 'Lagoa Redonda' colhidos em Limoeiro do Norte-CE em maturação fisiológica. Em seguida, os frutos foram transportados ao Laboratório de Química do IFCE Campus Limoeiro do Norte e armazenados por 8 dias a $29,7{ }^{\circ} \mathrm{C}$ e $59 \%$ de UR. O delineamento experimental foi o inteiramente casualizado em esquema fatorial $3 \times 5$, com três tipos de revestimento (controle, fécula de mandioca a $3 \%$ e fécula de mandioca a $3 \%$ associada ao filme de PVC) e cinco tempos de armazenamento ( 0 , 2, 4, 6 e 8 dias), com quatro repetições de cinco frutos por parcela. Avaliou-se a coloração da casca, aparência externa, teores de sólidos solúveis e de acidez titulável, relação SS/AT e a perda de massa. O uso do filme plástico foi eficiente na conservação da aparência externa e controle da perda de massa. O uso da fécula de mandioca não se mostrou tão eficiente quanto o filme plástico na conservação de cajás. A vida útil pós-colheita dos frutos foi de 8 dias para os tratados com fécula de mandioca ou fécula de mandioca associada ao PVC e de 6 dias para o controle.

Palavras-chave: Spondias mombin L.. Revestimento. Conservação. Vida útil.

\footnotetext{
*Corresponding author

${ }^{1}$ Received for publication in 06/06/2014; accepted in 08/05/2016.

Paper extracted from the Scientific Initiation Project of the first author (PIBIC/CNPq).

${ }^{2}$ Department of Food Technology, Instituto Federal de Educação, Ciência e Tecnologia do Ceará, Limoeiro do Norte, CE, Brazil; valdenice2006@yahoo.com.br, pahlevi10@hotmail.com.

${ }^{3}$ Department of Agronomic Enginering, Instituto Federal de Educação, Ciência e Tecnologia do Sul de Minas, Pouso Alegre, MG, Brazil; ecoelho@ifce.edu.br.

${ }^{4}$ Embrapa Agroindústria Tropical, Fortaleza, CE, Brazil; xavier.souza@embrapa.br.

${ }^{5}$ Department of Food Technology, Instituto Federal de Educação, Ciência e Tecnologia do Rio Grande do Norte, Pau dos Ferros, RN, Brazil; hirllen_nara@yahoo.com.br.
} 


\section{INTRODUCTION}

Mombin (Spondias mombin L., Anacardiaceae) is a high, tropical, woody, deciduous fruit tree, which has a long, straight trunk covered by a thick and rough bark, with branches at the top (SOUZA; BLEICHER, 2002). This tree is found in several states of Brazil and its fresh and processed fruits are increasingly demanded by the market, increasing its socio-economic importance and the farmers and agribusinesses interest on its commercial production (SOUSA; INNECO; ARAUJO, 1999).

Mombin fruits came to the attention of national and international producers, researchers, industries and markets due to its various possibilities of use, excellent nutritional characteristics and high potential for industrial processing. However, this fruit high perishability is one of the critical issues that hinder its feasibility throughout its production chain (MOREIRA et al., 2002). Therefore, the understanding of the biological and environmental processes involved in this fruit post-harvest deterioration is necessary and can be used as a basis to develop technologies to increase its post-harvest life and maintain the fruit quality (SAMPAIO et al., 2007).

Several conservation methods, such as cooling and modified atmosphere (VILA et al., 2007) are widely used to preserve the quality of fruits, which contribute to the reduction of post-harvest losses, by reducing the metabolic activity and water loss, maintaining their commercial characteristics. The use of modified atmosphere as a complementary measure to cooling, promotes a decrease in the fruit respiratory rate by increasing the $\mathrm{CO}_{2}$ and decreasing the $\mathrm{O}_{2}$ levels in the storage environment (RAI; OBEROI; BABOO, 2002).

The interest in developing formulations for films and edible coatings that can be applied to the surface of perishable products, such as blueberry (DUAN et al., 2011), eggplants (SOUZA et al., 2009), plums (EUM et al., 2009), guava (VILA et al., 2007), strawberry (RIBEIRO et al., 2007) and carrots (JAGANNATH et al., 2006), has been growing in recent years. This interest is due to the increasing demand for products that have high quality and longer post-harvest life, and sustainability of this process, which reduces the use of disposable packaging, developing recyclable or biodegradable packaging (CHITARRA; CHITARRA, 2005).

Edible film coatings have the same purpose of wax coating, using starch derivatives, cellulose or collagen as raw materials. The film application may be performed directly to the food surfaces, which may be consumed with the edible films. Cassava starch is considered the most suitable raw material for preparation of edible biofilms because it forms a resistant, transparent and efficient film that reduces water loss and makes fruits and vegetables commercially attractive due to the conservation of their organoleptic characteristics and maintenance of a good visual presentation (VILA, 2004).

The knowledge on and application of appropriate techniques is important to ensure the quality of fruit species, such as mombin, and reduce post-harvest losses. However, these techniques must be sustainable and consider local environmental conditions. Thus, the objective of this work was to evaluate the post-harvest characteristics of mombin fruits coated with cassava starch and PVC film.

\section{MATERIAL AND METHODS}

The mombin fruits (cultivar Lagoa-Redonda) used in the experiment were harvested, at physiological maturity, in an orchard of the Frutal Institute (Jaguaribe-Apodi Irrigation District) located in Limoeiro do Norte, State of Ceará (CE) $\left(5^{\circ}\right.$ $12^{\prime} 9.8^{\prime \prime} \mathrm{S}, 37^{\circ} 59^{\prime} 29.2^{\prime \prime} \mathrm{W}$, altitude of $158 \mathrm{~m}$ - GPS 12). The fruits were transported in covered plastic containers to the Food Chemistry Laboratory of the Federal Institute of Education, Science and Technology of Ceará (IFCE), Limoeiro do Norte campus, where they were selected and sanitized with an active chlorine solution (100 ppm) for 10 minutes.

One hundred fruits were coated with a cassava starch suspension $(3 \%)$ and one hundred were coated with the cassava starch suspension (3\%) combined with a $15 \mu \mathrm{m}$-thick, stretchable, self-adhesive polyvinyl chloride (PVC) film (Alp Film $\left.{ }^{\circledR}\right)$. Another 100 fruits were kept untreated (control). The fruits were stored at average temperature of $29.7^{\circ} \mathrm{C}$ and $59 \%$ of relative humidity, which were measured with a thermo-hygrometer (Minipa MT-241).

The starch emulsion was composed of 1 liter of water and $30 \mathrm{~g}$ of starch mixed at $70^{\circ} \mathrm{C}$ under constant stirring until gelation and rested until reaching room temperature.

A completely randomized experimental design in a $3 \times 5$ factorial arrangement was used, with three coating types (control, cassava starch at 3\%, and cassava starch at 3\% combined with PVC film) and five storage times $(0,2,4,6$ and 8 days), four replicates and five fruits per plot.

The following fruit characteristics were evaluated at the end of each storage time: external appearance, defined by a visual and subjective scale that ranges from 1 to 5 (LIMA et al., 2004), considering the absence or presence of defects, wilts and fungal attacks; skin color, evaluated by a visual and subjective scale that ranges from 1 to 5 , in which 1 is a completely green fruit, 2 is a $25 \%$ yellow skin fruit, 3 is a $50 \%$ yellow skin fruit, 4 is a $75 \%$ of yellow skin fruit, and 5 is a completely yellow fruit; soluble solids (SS), determined by a digital refractometer, using a filtered mombin juice, with results expressed as ${ }^{\circ}$ Brix; titratable acidity (TA) 
determined by titration of a sample of $10 \mathrm{~mL}$ of the juice with a $\mathrm{NaOH}$ solution $(0.1 \mathrm{~N})$, with results expressed as percentage of citric acid (IAL, 2008); and SS/TA ratio calculated the by ratio between soluble solids and titratable acidity. The weight loss was evaluated daily by the difference between the initial weight and the weight at each evaluation, with results expressed as percentages.

The data were subjected to analysis of variance (ANOVA). The qualitative factors were subjected to the Tukey's test at 5\% probability, and the quantitative factors, to regression analysis, using the software Table Curve (JANDEL SCIENTIFIC, 1991)

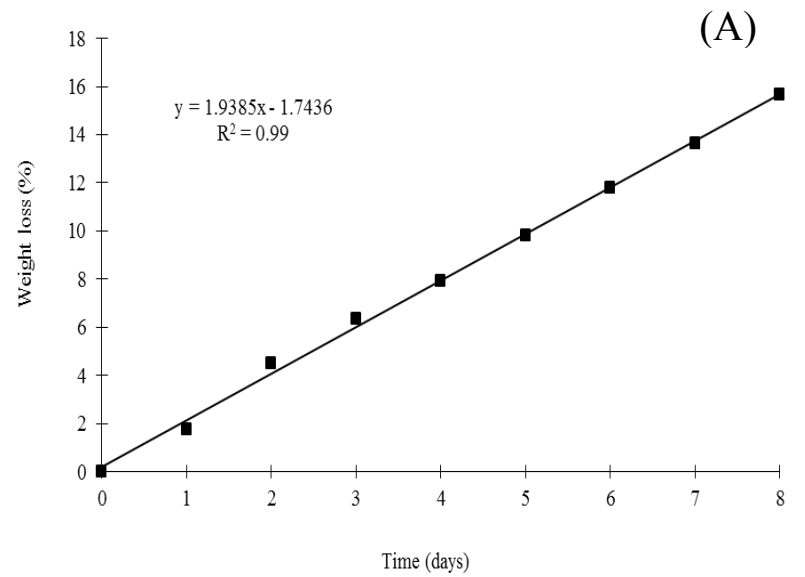

\section{RESULTS AND DISCUSSION}

The coating types and storage times showed a significant interaction with the titratable acidity (TA), color and external appearance of the fruits. The soluble solids (SS) and weight loss were affected by the coating types and storage times, and the soluble solids, weight loss and SS/TA ratio were affected by the storage time.

The fruit weight loss had a gradual increase throughout the storage period (Figure 1A), reaching a maximum loss of $15.66 \%$ after 8 days. The fruits coated only with starch showed greater weight loss, with an average of $10.76 \%$, approximately $26.02 \%$ higher than the other treatments, which changed the appearance of the fruits (Figure 1B).

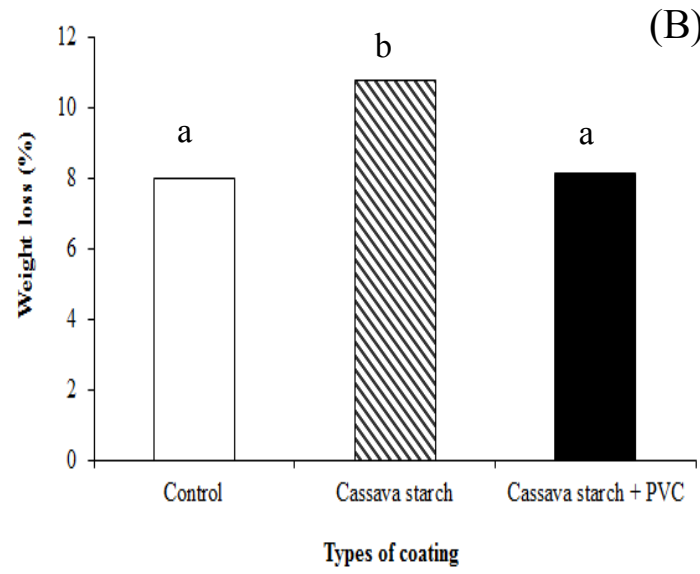

Figure 1. Weight loss of mombin fruits depending on the storage time (A) and different types of coating (B).

Weight loss occurs mainly due to moisture loss by transpiration. Cassava starch does not have a good moisture retention efficiency due to the starch chain structure, which in some cases may act as a hydrophilic substance, removing moisture from fruits.

Similar results were observed by Lemos et al. (2007), who evaluated the effects of biofilms of cassava starch at concentrations of 3,4 and $5 \%$ on the preservation of Magali- $R$ peppers under two storage conditions, and found that the biofilm did not reduce the weight loss at room temperature, while under refrigeration, the fruits treated with the biofilm lost more weight than the control. Vicentini et al. (1999), evaluating cassava starch coating at $1 \%$ and $3 \%$ on peppers, and Pereira et al. (2006), evaluating coating concentrations $(1,2$ and $3 \%)$ on papaya, found no significant decreases in weight loss, and lesser loss with increasing starch concentration.

According to Chitarra and Chitarra (2005), the use of hydrophilic coatings, such as starch, has limitations due to their water vapor barrier. Thus, some lipids or proteins must be added to these edible films to overcome this limitation.

Regarding the use of the plastic films, Al-ati and Hotchkiss (2003) found that the use of flexible films may increase the post-harvest life of fruits by modifying the storage atmosphere, minimizing water loss (CISNERO-ZEVALLOS; KROCHTA, 2002). Morreti and Pineli (2005), evaluated different atmospheres for eggplants storage at $12^{\circ} \mathrm{C}$ and found a lower weight loss compared with the control, using plastic films singly and combined with $\mathrm{CaCl}_{2}$. Thus, PVC films are effective in containing weight loss, probably due to a reduction in the fruit respiratory rate and formation of a physical barrier against water diffusion (VILA et al., 2007).

The soluble solids (SS) increase from 9.2 to $11.3{ }^{\circ}$ Brix (Figure 2A) throughout the storage period, with the highest levels on the $4^{\text {th }}$ day of storage. Regarding the types of coating, the fruits coated with starch combined with PVC showed the lowest SS contents (Figure 2B).

The SS increased probably due to the hydrolysis of the starch and changes in soluble sugar contents during the storage period. The fruits treated with starch combined with PVC had lower levels of SS probably due to an increase in their metabolic processes, which may have increased the consumption of SS components in the respiratory process. 

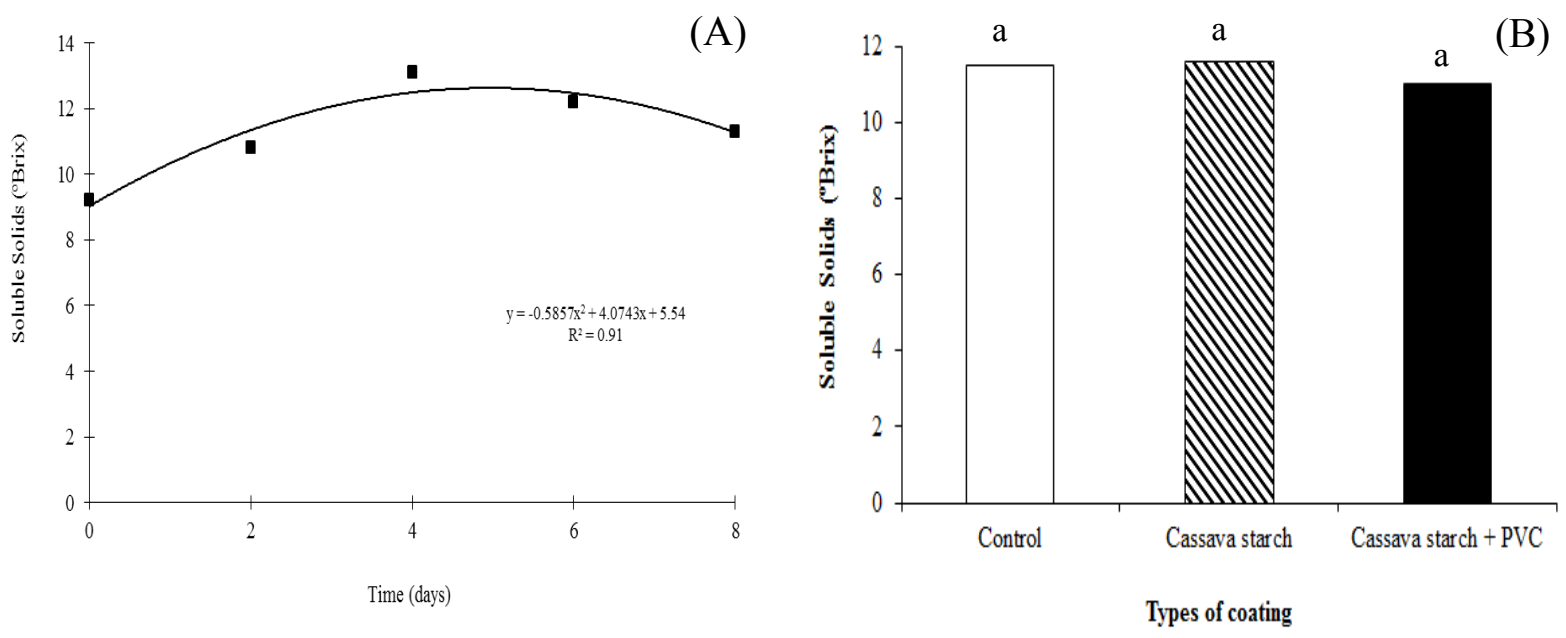

Figure 2. Soluble solids content ( ${ }^{\circ}$ Brix) of mombin fruits depending on the storage time (A) and different types of coating (B).

Filgueiras et al. (2000) found average levels of SS in mombin fruits of 10.3 (pre-completely yellow skin) to $11.3^{\circ}$ Brix (completely yellow skin). The authors also observed an increase in total SS, probably due to the conversion of carbohydrates, an increase in reducing sugars, and a decrease in starch content, which was found at small concentrations in the fruits.

SS consist of several compounds, including acids, pectins, phenolic compounds and especially sugars. Sampaio et al. (2007), evaluated the respiration of mombin fruits and found SS contents of 9.1 (ripened green) to $13.7^{\circ} \mathrm{Brix}$ (maximum climacteric).

The titratable acidity levels increased regardless of the type of coating up to the $6^{\text {th }}$ day of storage, with a subsequent decrease mainly in fruits coated with starch combined with PVC film (Figure 3A). The SS/TA ratio increased throughout the fruit storage, with initial and final averages of 5.8 and 7.4, respectively (Figure $3 \mathrm{~B}$ ).
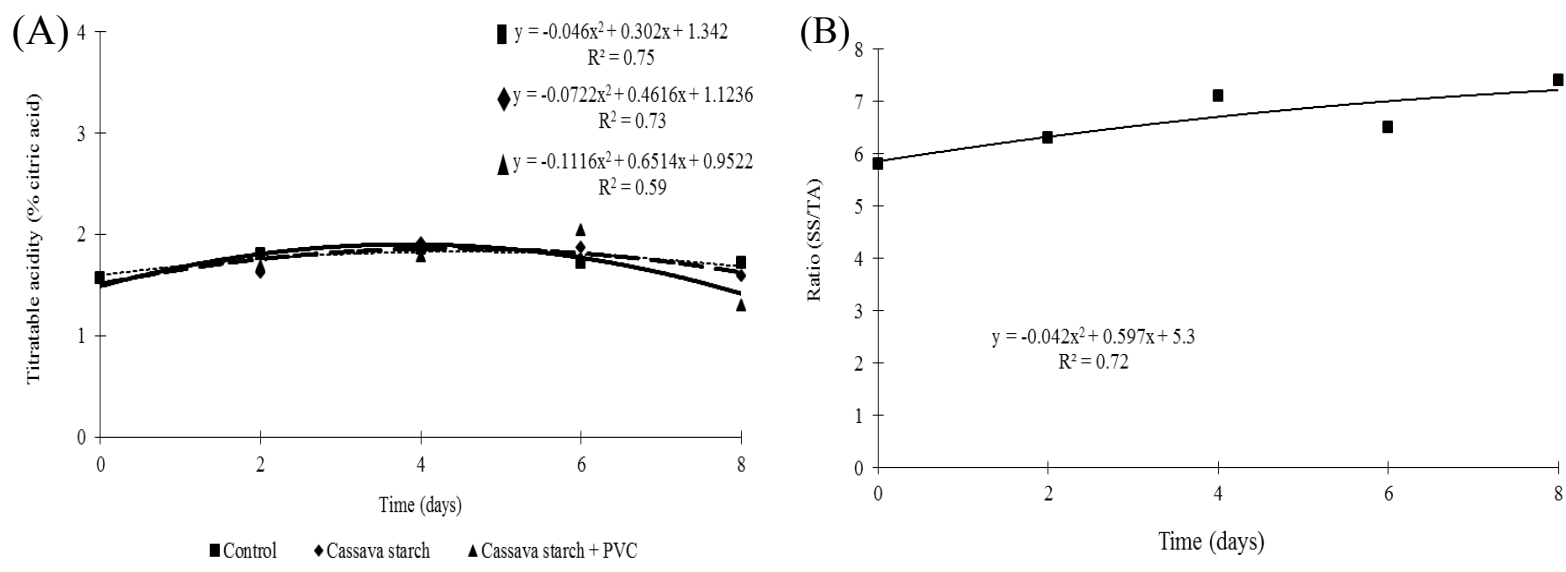

Figure 3. Titratable acidity of mombin fruits with different coatings (A) and SS/TA ratio (B) depending on the storage time.

The fruits coated with starch combined with PVC showed a greater decrease of titratable acidity at the end of the experiment, indicating a change in metabolic processes, which increased the consumption of acids by the respiratory process. According to Chitarra and Chitarra (2005), the fluctuation in titratable acidity contents with fruit storage time may be related to biochemical processes of the respiratory metabolism, which synthesizes and consumes organic acids.

The soluble solid contents found in the present work (11.23 ${ }^{\circ}$ Brix $)$ were below the values found by Filgueiras et al. (2000). The total soluble solid and titratable acidity ratio is related to the sugar and acid balance of fruits, which is an important indication of flavor. The determination of this relation is important, since some fruits containing low levels of acids and soluble solids have high SS/ TA ratios, which may lead to misinterpretations of organoleptic characteristics.

The external appearance of the fruits lost quality throughout the experimental period, 
regardless of the treatments (Figure 4A). The fruit skin color had a less intense change from green to orange in the coating treatments using starch and

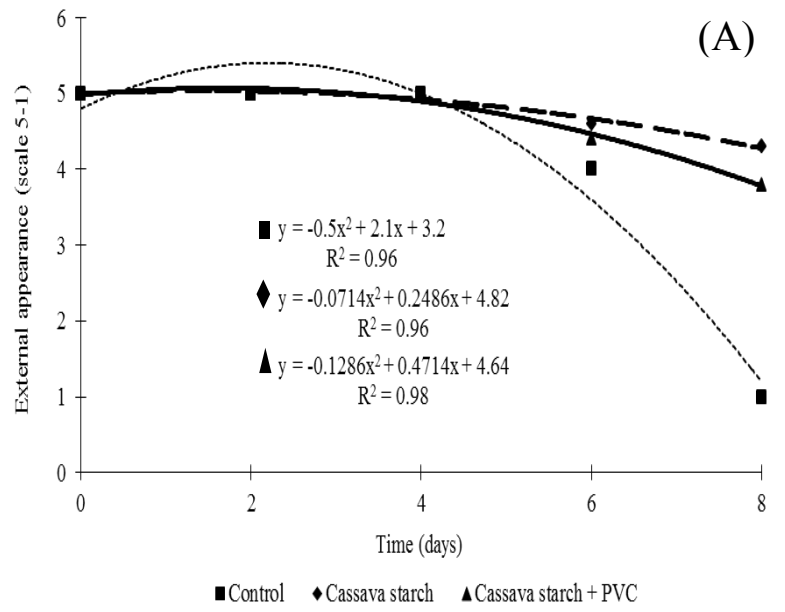

starch combined with PVC, keeping a green skin until the end of the experiment (Figure 4B).

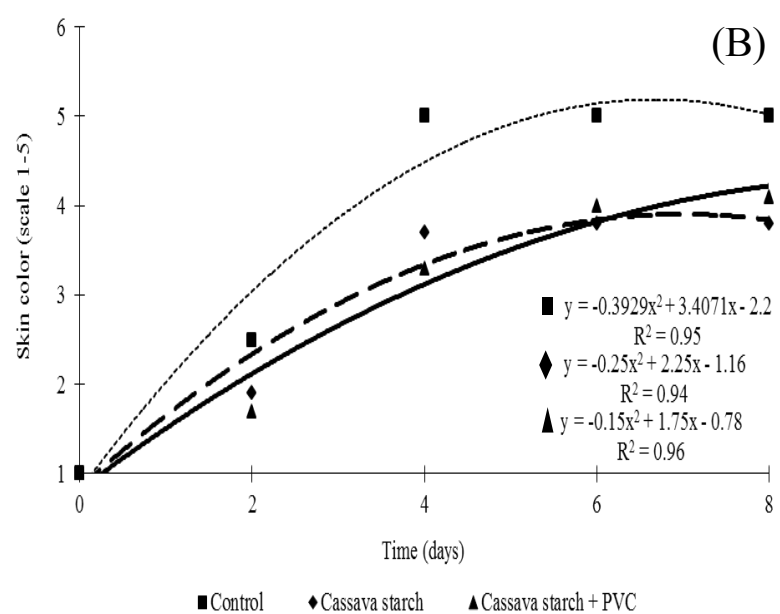

Figure 4. External appearance (A) and skin color (B) of mombin fruits with different coatings depending on the storage time.

The control fruits were unfit for consumption (score 1) at the end of the experiment, whereas the fruits of other treatments were still marketable (scores higher than 3). The loss of external appearance was mainly due to wilting, loss of gloss, uneven skin and fungal attacks. The fruit external appearance is the most important quality factor from the marketing point of view (CHITARRA; CHITARRA, 2005), which is evaluated through several attributes such as freshness, size, shape, color, cleanliness, maturity stage and defects.

Vicentini et al. (1999), evaluating peppers, found a delay in color change due to the decrease in $\mathrm{O}_{2}$ and increase in $\mathrm{CO}_{2}$ levels, thus, the film is not completely permeable to $\mathrm{O}_{2}$ and $\mathrm{CO}_{2}$, although it is to water. According to Wills et al. (1998), chlorophyll degradation occurs due to changes in $\mathrm{pH}$, action of acids, increases in oxidative processes and action of chlorophyllase. The maintenance of the green color may be related to a lower penetration of oxygen into the fruit, reducing the synthesis of chlorophyllase, which is mediated by ethylene.

\section{CONCLUSIONS}

The use of plastic film as fruit coating is effective in maintaining the fruit external appearance and reducing weight loss.

The results found with the use of cassava starch as fruit coating were not satisfactory compared with the cassava starch combined with PVC film, however, those showed better results compared with the control treatment.

The period for conservation of mombin fruits without changes in their external appearance was 8 days for the fruits coated with cassava starch or cassava starch combined with PVC film, and 6 days for the control fruits.

\section{REFERENCES}

AL-ATI, T.; HOTCHKISS, J. H. The role of packaging film permeselectivity in modified atmosphere packaging. Journal of Agricultural and Food Chemistry, Davis, v. 51, n. 14, p. 4133-4138, 2003.

CHITARRA, M. I. F.; CHITARRA, A. B. Pós-colheita de frutos e hortaliças: fisiologia e manuseio. 2. ed. Lavras, MG: UFLA, 2005. 785 p.

CISNERO - ZEVALLOS, L.; KROCHTA, J. M. Internal modified atmosphere of coated fresh fruit and vegetables: Understanding relative humidity effects. Journal of Food Science, Chicago, v. 67, n. 8, p. 2792-2797, 2002.

DUAN, J. et al. Effect of edible coatings on the quality of fresh blueberries (Duke and Elliott) under commercial storage condition. Postharvest Biology and Technology, Amsterdam, v. 59, n. 1, p. 71-79, 2011.

EUM, H. L. et al. Influence of edible coating on quality of plum (Prunus salicina Lindl. cv. 'Sapphire'). European Food Research Technology, Amsterdam, v. 229, n. 3, p. 427-434, 2009.

FILGUEIRAS, E. A. C.; MOURA, C. F. H.; ALVES, R. E. Cajá (Spondias mombin L.). Disponível em: <http:// www.ceinfo.cnpat.embrapa.br/arquivos/ artigo_1554.pdf.> Acesso em: 15 jul. 2010. 
INSTITUTO ADOLFO LUTZ. Normas analíticas, métodos químicos e físicos de alimentos. 4. ed. São Paulo, SP: IAL, 2008. 1020 p.

JAGANNATH, J. H. et al. Studies on the stability of an edible film and its use for the preservation of carrot (Daucus carota). International Journal of Food Science and Technology, New York, v. 41, n. 5, p. 498-506, 2006.

JANDEL SCIENTIFIC. User's Manual. Califórnia: Jandel Scientific, 1991. 280 p.

LEMOS, O. L. et al. Utilização de Biofilmes comestíveis na conservação de pimentão 'Magali R' em duas condições de armazenamento. Bragantia, Campinas, v. 66, n. 4, p. 693-699, 2007.

LIMA, M. A. C. et al. Conservação de melões Gália 'Solar King' tratados com 1-metilciclopropeno. Horticultura Brasileira, Brasília, v. 22, n. 1, p. $121-126,2004$.

MOREIRA, M. A. B. et al. Cajá (Spondias mombin L. sin Spondias lutea L.). In: VIEIRA NETO, R. D. (Ed.). Frutíferas potenciais para os tabuleiros costeiros e baixadas litorâneas. Aracaju: Embrapa / Endagro, 2002. v. 1, cap. 2, p. 22-44.

MORETTI, C. L.; PINELI, L. L. O. Qualidade química e física de berinjelas submetidas a diferentes tratamentos pós-colheita. Ciência e Tecnologia de Alimentos, Campinas, v. 25, n. 2, p. 339-344, 2005.

PEREIRA, M. E. C. et al. Amadurecimento de mamão formosa com revestimento comestível à base de fécula de mandioca. Ciência e Agrotecnologia, Lavras, v. 30, n. 6, p. 1116-1119, 2006.

RAI, D. R.; OBEROI, H. S.; BABOO, B. Modified atmosphere packaging and its effect on quality and shelf-life of fruits and vegetables - An overview. Journal of Food Science and Technology, Mysore, v. 39, n. 3, p. 199-207, 2002.

RIBEIRO, C. et al. Optimization of edible coating composition to retard strawberry fruit senescence. Postharvest Biology and Technology, Amsterdam, v. 44, n. 1, p. 63-70, 2007.

SAMPAIO, S. S. et al. Postharvest respiratory activity and changes in some chemical constituents during maturation of yellow mombin (Spondias mombin) fruit. Ciência e Tecnologia de Alimentos, Campinas, v. 27, n. 3, p. 511-515, 2007.

SOUZA, F. X.; BLEICHER, E. Comportamento da cajazeira enxertada sobre umbuzeiro em Pacajus, CE. Revista Brasileira de Fruticultura, Jaboticabal, v. 24, n. 3, p.790-792, 2002.
SOUZA, F. X.; INNECO, R.; ARAÚJO, C. A. T. Métodos de enxertia recomendados para a produção de mudas de cajazeira e de outras frutíferas do gênero Spondias. Fortaleza: Embrapa Agroindústria Tropical, 1999. 8 p. (Comunicado Técnico, 37).

SOUZA, P. A. et al. Conservação pós-colheita de berinjela com revestimentos de fécula de mandioca ou filme de PVC. Horticultura Brasileira, Brasília, v. 7, n. 2, p. 235-239, 2009.

VICENTINI, N. M.; CASTRO, T. M. R.; CEREDA, M. P. Influência de películas de fécula de mandioca na qualidade pós-colheita de frutos de pimentão (Capsicum annuum L.). Ciência e Tecnologia de Alimentos, Campinas, v. 19, n. 1, p. 127-130, 1999.

VILA, M. T. R. et al. Caracterização química e bioquímica de goiabas armazenadas sob refrigeração e atmosfera modificada. Ciência e Agrotecnologia, Lavras, v. 31, n. 5, p. 1435-1442, 2007.

VILA M. T. R. Qualidade de goiaba 'Pedro Sato' armazenados sob refrigeração e atmosfera modificada por biofilme de fécula de mandioca. 2004. 66 f. Dissertação (Mestrado em Ciência dos Alimentos) - Universidade Federal Lavras, Lavras, 2004.

WILLS, R. et al. Introducción a la fisiologia $\mathbf{y}$ manipulación poscoseha de frutas, hortalizas $y$ plantas ornamentales. Tradução de J. B. Gonzáles. 2. ed. Zaragoza: Acribia, 1998. 240 p. 